IJJM

Ilomata International Journal of Management

P-ISSN: 2714-8971; E-ISSN: 2714-8963

Vol. 1 No. 2 March 2020 pp. 65-71

https://www.ilomata.org/index.php/ijim

\title{
Moonlighting, Harm? : Student Perception of the Effect of Moonlighting, Achievement Motivation on Lecturer Performance
}

\author{
Hartina Fattah ${ }^{1}$, Andi Batari Citta ${ }^{2}$ \\ ${ }^{1}$ STAI YAPNAS Jeneponto \\ ${ }^{2}$ STIM Lasharan Jaya Makassar \\ thinafattah@gmail.com, citta2585@gmail.com
}

Submitted: February $10^{\text {th }}, 2020$

Revised: March 10th 2020

Published: March 30th, 2020

\begin{abstract}
This study aims to determine students 'perceptions of the term moonlighting lecturers and find out the effect of moonlighting on lecturers' performance which is mediated by achievement motivation. This study uses quantitative methods with path analysis based on data from 145 student respondents in private universities in Jeneponto Regency. The results of the study showed that students perceive moonlighting as a natural thing for lecturers to do as an alternative to meet the needs of lecturers. The findings indicate that moonlighting has a significant positive indirect effect which is mediated by the achievement motivation of lecturers on the performance of lecturers.
\end{abstract}

Keywords: moonlighting, achievement motivation, lecturer performance, student perceptions

\section{INTRODUCTION}

The term moonlighting, according to The American Heritage Dictionary, means working in a sequential, part-time and usually night job (Ologunde, Akindele, \& Akande, 2013). This term can also mean side jobs. Nowadays, meeting people who have two, three or more jobs at the same time is not surprising anymore. Moonlighting lecturers can be interpreted by lecturers who work as teaching staff in several universities (additional work) on the grounds of individual lecturers themselves or college needs that receive lecturers involved in that part-time.

Why do some people choose Moonlighting? Shisko and Rostker (1976), O'Connell (1979), and Krishnan (1990), the people select moonlight because of constraints the main work related to economic conditions and other factors, workers not work or earn as much they want the primary job, with thus workers consider taking the second job. The decision to work side-byside is very dependent on the demand for labor and income derived from the second job, and the decision to do moonlight is very reliant on the number of hours worked on the main task (Kimmel \& Conway, 1996). Likewise with the research conducted by Boateng, Adjei, \& Oduro (2013) concluded that regardless of the financial motives that drive individual decisions for moonlighting, moonlighting's involvement due to lower working hours in the single main work can be a visible or related endpoint time.

On the loose conversation with several lecturers who conducted moonlighting revealed that the underlying motives for taking part jobs varied, but never separated from the desire for success or achievement, at least, did not fail to meet their personal or family needs. It can mean that moonlighting can contribute to achievement motivation because achievement motivation is 
Moonlighting, Harm? : Student Perception of the Effect of Moonligthing, Achievement Motivation on Lecturer Performance

Fattah, Citta

an internal process that activates, guides and maintains behavior over time. Individuals motivated for a variety of different reasons, with different intensities.

Achievement motivation McClelland in Djaali (2007) states that motivation will always be associated with achieving some standards of intelligence or skill standards. Meanwhile, according to Heckhausen in Djaali (2007), achievement motivation is the drive contained in individuals who are always trying or struggling to improve or maintain their abilities as high as possible in all activities using standards of excellence, thus reflecting high needs. For achievement (achievement), (Robbins and Judge, 2009: 215), namely: 1) The desire to accept responsibility for solving problems. 2) Tend to set goals and achievements that are moderate and tend to take calculated risks. 3) The willingness to receive feedback about performance.

The success of a Lecturer as an educator can show from the performance assessment of lecturers. Lecturer performance evaluation is critical to do at a college institution. For the performance assessment results of lecturers to be considered valid, the review can be carried out by several parties, among others, direct supervisors, leaders, fellow lecturers and students as users. The results of the assessment of qualified lecturers' performance have a positive effect on universities (Foon, Yeoh Sok, Yin, \& Fah, 2012). In other words, quality universities lie in the quality of the lecturers themselves (Lestari, 2018).

Students in the quality indicator system in higher education have a dual position, namely as a subject as well as an object in the implementation of higher education tri dharma or in other words as assets of higher education human resources in carrying out the tri dharma of higher education as well as user services in the process of learning. The rights representative assesses matters relating to the quality of higher education, including satisfaction in obtaining quality education services. So that in this study, the perceptions of students are very decisive in the assessment of lecturer performance, moonlighting, which based on the achievement motivation of lecturers. The following diversity of backgrounds or characteristics students so that many perceptions arise towards the performance assessment of the lecturer. According to Widiawati (2014), the results of the lecturer performance assessment will be a recommendation for lecturers whether the lecturer has excellent quality performance or vice versa. So the results of performance appraisal can be an evaluation and benchmark for the success of lecturers in teaching.

Perception is a process by which individuals organize and interpret their sensory impressions to give meaning to their environment (Stephen, 2008). Furthermore, Stephen (2008) describes the perception factors as follows: 
Moonlighting, Harm? : Student Perception of the Effect of Moonligthing, Achievement Motivation on Lecturer Performance

Fattah, Citta

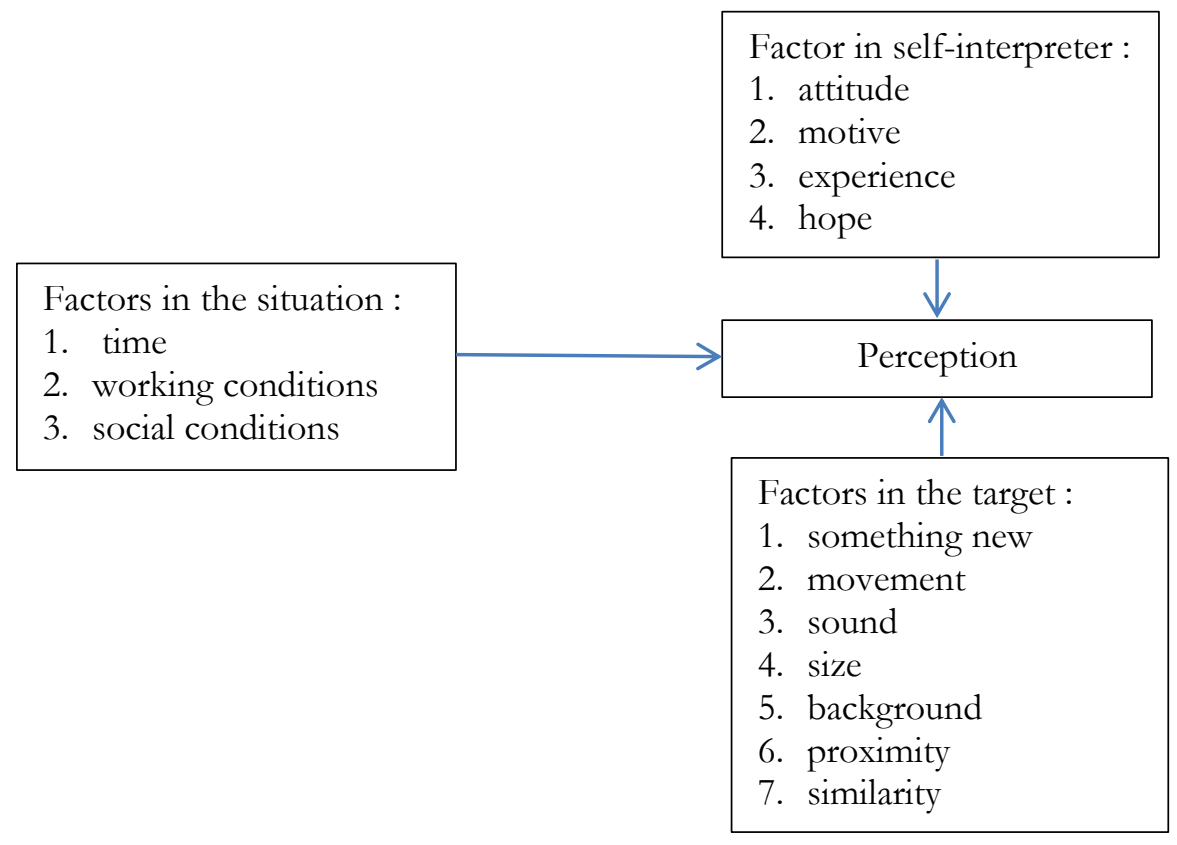

Figure 1. Overview of Perception

Factors influence the existence the phenomenon of moonlighting lecturers by Ologunde et al. (2013) et al., namely (1) the increasing number of private tertiary institutions in Nigeria while the number of teaching staff is still lacking; and (2) Lecturer motivation factors which are characterized by welfare, working conditions, attitudes, promotion and infrastructure of higher education which are the causes of many lecturers choosing a profession as a moonlight lecturer. Whereas Yamb \& Bikoue (2016) show that the moonlighting determinant of lecturers is very dependent on the primary job salary, the limitation of working hours on the main job and income from the second job or side job. Ara \& Akbar (2016) identified four factors that influence moonlighting, namely additional income, blocked promotions, diversity skills, and work autonomy. The four factors that influence moonlighting behavior have a significant impact on job satisfaction.

The results of Shisko \& Rostker's (1976) study show that moonlighting labor offers increased along with the increase in the level of income of second jobs, but on the contrary, fell when the income of the leading role improved. Whereas Dickey, Watson, \& Zangelidis (2009) found that not only financial motives can explain the moonlighting phenomenon, but also other factors, such as flexibility of work schedules, satisfaction levels obtained from secondary jobs, even because of opportunities for entrepreneurship.

According to Ologunde et al. (2013), teaching in various places (moonlighting) harms individual lecturers and lecturer performance. His findings are in line with Ekaette (2006); Oyaziwa (2005); Sofola (2005), namely the existence of a negative relationship between the number of meeting hours per week and the number of universities where lecturers teach. Implies that the higher the number of lecturers' teaching places (universities), the lower the numbers of meetings per week at all universities where the lecturer teaches. The research conducted by Olugande (2005) shows a significant difference in the name of research publications by lecturers who teach at one university and lecturers who teach at more than one university. 
Moonlighting, Harm? : Student Perception of the Effect of Moonligthing, Achievement Motivation on Lecturer Performance

Fattah, Citta

Mc Clelland first popularized the term Need for achievement as n-act as an abbreviation of the need performance. Mc Clelland regards n-act as a mental virus. The mental illness is a thought that is related to how to do things well, faster more efficiently than what has done before mental illness behaves actively (Weiner, 1985). According to McCelland (1986), the notion of achievement motivation defined as an effort to achieve success or success in competition with a measure of excellence that can be in the form of other people's achievements or their achievements. Lindgren (1976), the something achievement motivation an impulse exists someone concerning performance. Namely, mastering, manipulating fibre regulates the social and physical environment, overcomes all obstacles and maintains high-quality work, competences through efforts to exceed results past work, and outperform other work.

Regarding the performance of lecturers, be categorized in individual performance because each lecturer has different qualifications and motivations in carrying out his profession. For own performance, Mathis, Robert, and L Jackson (2008) state that organizational performance determined by the performance of individuals in that organization. Albanes and Soelaiman Sukmana (2009) specify individual performance factors in three factors; (a) abilities and skills, (b) role perception, and (c) effort or motivation. In line with Albanes and Soelaiman Sukmana (2009), the theory of Mathis, Robert L, and Jackson (2008) also suggests factors that influence individual performance in three factors, namely; (a) own ability to do work, (b) effort level expended, and (c) organizational support.

Based on the statement about performance as it concluded that what is meant by lecturer performance is the performance or achievement of work performed by the lecturer in carrying out their duties. The main task of the lecturer is to implement the Tri Dharma of Higher Education, namely implementing education and teaching, research, and community service. More precisely, the performance of the lecturer interpreted as the quantity and quality of work completed by the lecturer following the binding rules in the tertiary institution and applicable legislation. In this study, the meaning of lecturer performance is to refer to lecturer performance indicators based on the dimensions of teaching that can be assessed concretely by students

\section{METHOD}

This study uses a quantitative approach with path analysis methods in the data analysis technique. This study uses path analysis because, among the independent variables (Moonlighting) with dependent variables (Lecturer Performance), there is an influencing mediation (achievement motivation variable). The population in this study were all students residing in 4 (four) private universities in Jeneponto district. The sampling technique as done randomly. The questionnaire was used as an instrument to collect primary data from respondents. Of the 200 questionnaires distributed there were 145 questionnaires that were filled in entirely by respondents $(75.12 \%$ of the surveys distributed). To calculate scores on questionnaire items, researchers used a Likert scale. The scale of several questions arranged with the respondent's answers in a continuum given the weight according to the issue, with alternative solutions: strongly agree, agree, neutral, disagree, strongly disagree. The variable indicators tested in this study consisted of 2 symbols on moonlighting (number of teaching hours, additional income); 3 indicators on variable achievement motivation (self-confidence, self-control and 
Moonlighting, Harm? : Student Perception of the Effect of Moonligthing, Achievement Motivation on Lecturer Performance

Fattah, Citta

vitality) and three indicators on lecturer performance variables (teaching, research and community service).

\section{RESULT AND DISCUSSION}

The student's perception of moonlighting conducted by the lecturer provides the following description:

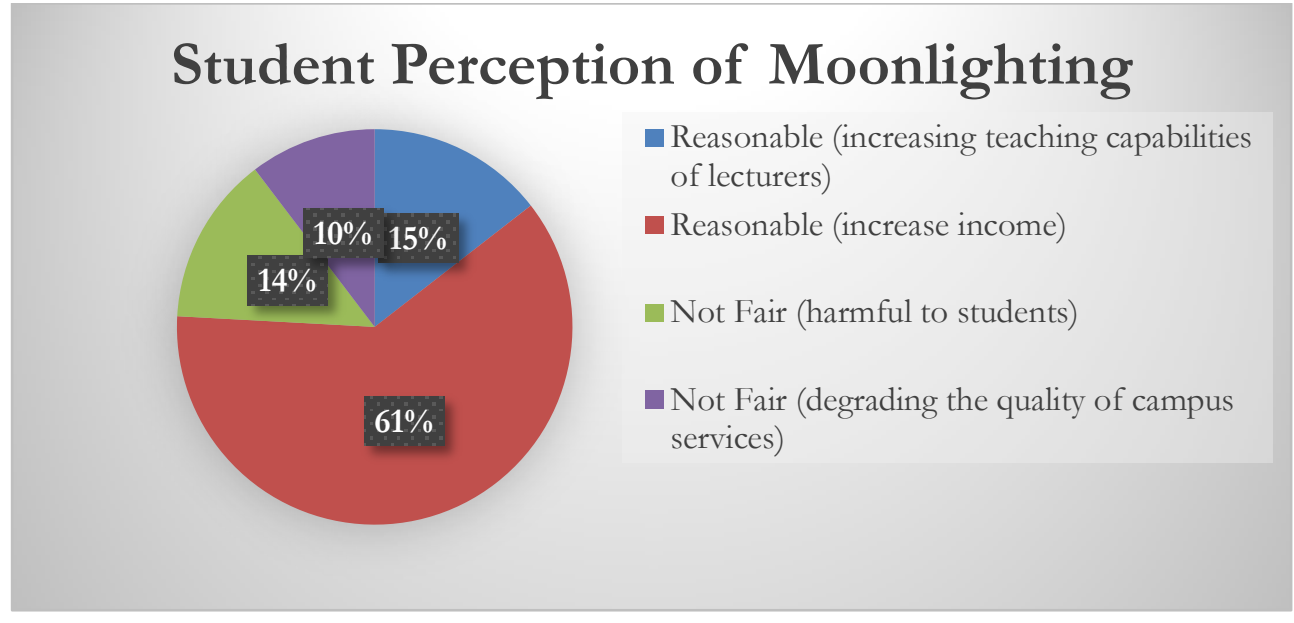

Source: Primary Data Processing, 2018

The path analysis test between variables gives the following calculation results:

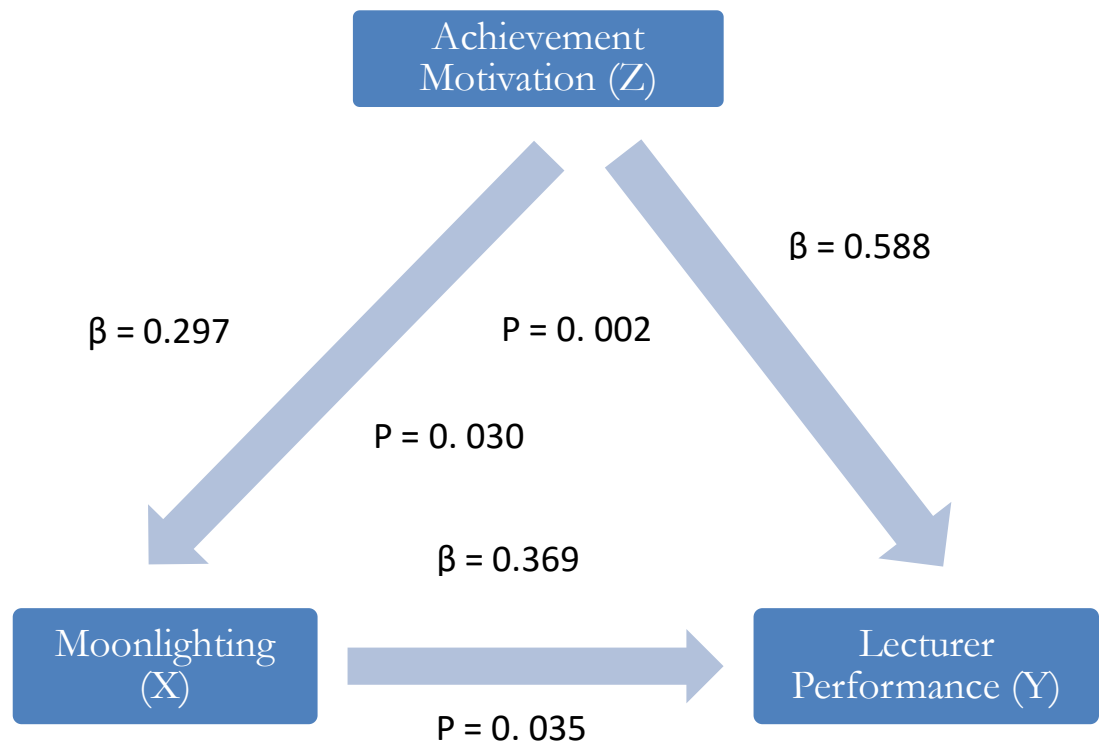

Source: Primary Data Processing, 2018

Based on the trajectory model of influence (path analysis) in the picture above, the effect of the error is determined as follows:

Effect of $X \rightarrow Z:$ Pc1 $=\sqrt{1-R_{1}^{2}}=\sqrt{1-0.562}=0.438$

Effect of $\mathrm{Z} \rightarrow \mathrm{Y}: \mathrm{Pc} 2=\sqrt{1-R_{1}^{2}}=\sqrt{1-0.136}=0.929$

$R_{m}^{2}=1-P_{e 1 \times}^{2} P_{e 2}^{2}$

$R_{m}^{2}=1-0.438^{2} \times 0.929^{2}$ 
Moonlighting, Harm? : Student Perception of the Effect of Moonligthing, Achievement Motivation on Lecturer Performance

Fattah, Citta

$R_{m}^{2}=0.834$

Based on the path analysis above, there is an influence between moonlighting through significant achievement motivation on performance, meaning that moonlighting through achievement motivation can improve the performance of lecturers. Where performance is directly affected by moonlighting at 0.369 or in other words, the higher the moonlighting, the higher the performance of lecturers. Moonlighting indirectly affects Performance through achievement motivation of $0.297 \times 0.588=0.175$. When viewed from the calculation of the effect of errors, moonlighting, and achievement motivation have an effect of 0.834 or $83.4 \%$ on performance, and the remainder is $16.6 \%$ by other factors.

\section{CONCLUSION}

This study provides a different perspective from the study of Ologunde et al., (2013), Ekaette (2006); Oyaziwa (2005); Sofola (2005), as mentioned in the literature review section above. Moonlighting is a counterproductive event related to the performance of lecturers, but the uniqueness of research/reports/news that states that moonlighting is detrimental and harms the performance of lecturers, but the fact is that moonlighting is increasingly prevalent. Even college demands that use the services of moonlighter lecturers have never subsided. If moonlighting has a negative or harmful impact on performance, there should be sanctions that can eliminate the quantity of moonlighting. Still, there are no sanctions that can deter lecturers from doing moonlighting, even though lecturers often feel proud to be called flying lecturers or extraordinary lecturers - as lecturers moonlighter. The absence of clear and explicit rules/laws regarding moonlighting also contributed to the negative / negative value of moonlighting on the performance of lecturers.

This thought reminds the author of bacteria. Bacteria are often considered as detrimental to humans because they can cause disease. However, it turns out we also need bacteria in our bodies to strengthen our immune system. Bacteria can convert food into nutrients, make vitamins $\mathrm{B}$ and $\mathrm{K}$, digest food, trigger the formation of antibodies, and inhibit harmful bacteria in our bodies. Well, the author's assumption of moonlighting might be detrimental. Still, with the persistence of moonlighting and the absence of strict regulations, it is also possible that moonlighting has a positive impact on the performance of lecturers. And this study provides an answer to the author that not all students consider moonlighting as harmful. Still, it deemed to be natural as an alternative to income, and this study also outlines that moonlighting through achievement motivation can improve the performance of lecturers. So ??? Keep researching. Hopefully, our scientific knowledge will expand.

\section{REFERENCE}

Ara, K., \& Akbar, A. (2016). A Study of Impact of Moonlighting Practices on Job Satisfaction of the University Teachers. Bulletin of Education and Research, 1(38), 101-116.

Boateng, W. B., Adjei, P., \& Oduro, A. D. (2013). Determinants of moonlighting in Ghana: an empirical investigation. African Review of Economics and Finance, 4(2).

Dickey, H., Watson, V., \& Zangelidis, A. (2009). What Triggers Multiple Job Holding? An Experimental Investigation. Research Gate. 
Moonlighting, Harm? : Student Perception of the Effect of Moonligthing, Achievement Motivation on Lecturer Performance

Fattah, Citta

Ekaette, U. (2006). Tasks Varsities on Quality Graduates. The Punch Newspaper.

Foon, Yeoh Sok, Yin, J. H. S., \& Fah, B. C. Y. (2012). Student Evaluation of Lecturer Performance Among Private University Students. Canadian Social Science, 8(4), 238-243. https://doi.org/10.3968/j.css.1923669720120804.3022

Kimmel, J., \& Conway, K. S. (1996). Who Moonlights and Why? Evidence from the SIPP.

Lestari, V. N. S. (2018). Analisis Rasio Keuangan Untuk Menilai Kinerja Keuangan Pada Pt. Indofood Sukses Makmur, Tbk, Di Bursa Efek Surabaya (Bes) Periode 1998-2002.

Ologunde, A. O., Akindele, R. I., \& Akande, W. O. (2013). Moonlighting Among University Lecturers and Their Performance in South-Western Nigeria. Journal of Management and Sustainability, 3(4). https://doi.org/10.5539/jms.v3n4p92

Olugande, A. (2005). Motivation and Labour Turnover among University Teachers in Southwestern, Nigeria. Obafemi Awolowo University Nigeria: The Department of Management and Accounting.

Oyaziwa, A. (2005). Enhancing Capacity Building in Educational Science in Nigeria Universities : How Higher Education Manager Can Help. European Journal of Educational Studies.

Shisko, R., \& Rostker, B. (1976). The Economics of Multiple Job Holding. The American Economic Review, 66(3), 298-308.

Sofola, S. (2005). The Future of Public Universities.

Stephen, R. (2008). Perilaku Organisasi (12th ed.). Salemba Empat.

Timothy, V. L., \& Nkwama, S. (2017). Moonlighting among teachers in urban Tanzania: A survey of public primary schools in Ilala District. Cogent Education, 4(1). https://doi.org/10.1080/2331186X.2017.1334434

Widiawati, K. (2014). Persepsi Mahasiswa Dalam Menilai Kinerja Dosen Melalui Evaluasi Umpan Balik Dosen (Eub) Di Akademi Sekretari Dan Manajemen Bina Insani. Jurnal Administrasi Kantor, 2(2).

Yamb, B., \& Bikoue, M. (2016). The Determinants of Moonlighting among Lecturers of State Universities in Cameroon: An Evidence from a Log-Linear Model. Research in Applied Economics, 8(3), 19. https://doi.org/10.5296/rae.v8i3.8795 